\title{
Big and Small Stories from India in the COVID19 Plot: Directions for a 'Post Coronial' Psychology
}

\author{
Parul Bansal ${ }^{1}$
}

Accepted: 20 October 2020 / Published online: 29 October 2020

(C) Springer Science+Business Media, LLC, part of Springer Nature 2020

\begin{abstract}
The paper has a dual focus. One, is to use India as a case study to reflect upon the political, economic and socio-cultural structures of the country and how they shape the particular vulnerabilities in the society which have been aggravated in the COVID19 crisis-scape. Stories about Indian democracy, Casteism and Untouchability, Hindutva and Islamophobia emerging from the pandemic scenario have been extended to show global parallels. Stories of cultural resourcefulness and examples of people's power in the Indian context have also been represented to provide a formative assessment of how India is faring in the pandemic crisis. Two, it gathers emergent questions about human and social life which are being re-emphasized and created by the pandemic for Psychology to focus on. It makes use of Indian psychological concepts to re-envision self-other relationships in Post Coronial world. It makes a plea for strengthening the critical-cultural approach in 'Post-Coronial' Psychology.
\end{abstract}

Keywords COVID19 · Democracy · Untouchability · Islamophobia - Cosmic collectivism · Indigenous psychology

Pandemics are complex emergencies. The COVID19 pandemic attests to it. No longer just a public health emergency, it has spiraled into humanitarian crisis of epochal proportions and our political, economic and psychological systems have come crashing down. It is the writing on the wall that we are living in Anthropocene, an epoch in which human activities have profoundly adversely altered the planet's geological, hydrological, bio-geochemical and atmospheric cycles. Evidently, we chose to turn a blind eye to all the warning signs.

Within the COVID19 crisis-scape, many stories are unfolding -personal and social, of resilience and breakdown, transformational and apocalyptic. In this paper, I narrate few chosen stories. These stories emerge from the Indian context but have global

Parul Bansal

parulintouch@gmail.com

1 Lady Shri Ram College For Women, University of Delhi, Delhi, India 
resonance. They have been chosen to be told because they reflect on our shared human condition; because they propel us to question the givens and imagine the alternatives. Globally, the COVID19 crisis has held up an X-ray of the fundamental structures of the human societies it has ravaged. It revealed who has more and who has less. Where the power lies. What is broken in a society. What offers hope in a society. The paper uses India as a case study and the COVID19 crisis-scape as the backdrop to reflect upon the political, economic and socio-cultural structures of the country and how they shape the particular vulnerabilities in the society which have been aggravated in the current scenario. It is a psycho-political commentary on how the virus aligns with various other ideological viruses present in the polity and moves along the fault lines created by poverty, caste and religion. In doing so, the paper shows the relevance of psychological knowledge to analyze the significance of socio-political constructs such as nationalism, class, casteism and untouchability, Hindutva and Islamophobia in the lived experience of Indians. The paper also presents cultural - psychological reflections on the wisdom of ancient Indic practices of Yoga and Ayurveda and ancient Indic texts such as Ramayana and Mahabharata which provide ways of combating this emergency. Another important aim of the writing is to gather the emergent questions about human and social life thrown by the pandemic crisis for psychology to focus on. It makes use of Indian psychological concepts to re-formulate self-other relationships in Post Coronial world. In order to re-envision the 'Post Coronial World', the paper strives to lay out certain directions for the 'Post Coronial Psychology' along the goal posts of criticalcultural approach.

In order to think of the viruses, one needs to engage with the shock of what they generate. So, I begin with my personal musings about the everyday experiences, impressions, dilemmas and feelings that I underwent as the pandemic created a sudden disjuncture through India and the world. In the autoethnographic spirit, I present in this section a snapshot of the dominant sentiments and concerns of the nation, from my standpoint, in the initial four to five months of the pandemic.

\section{Lockdown Diary: Living Through the Pandemonium in an Indian City}

As I write this paper in mid July, 2020, India has 1.08 million active cases of COVID19. Currently, it stands third in terms of infected cases, behind United States and Brazil. India was put under lockdown on March 25, and it continued for 74 days till 7th June with each phase of lockdown witnessing some relaxation of movement and economic activities. On 8th June, Unlock 1.0, kicked in, primarily with an aim to revive economy, even though India is steadily climbing the graph of COVID19 cases. Every alternate day marks a record spike in the number of reported cases. Everyday thirty to forty thousand new cases are being added. India's financial capital Mumbai and political capital New Delhi are the two worst affected cities. As of now, the urban cities and towns are being seen as the hubs of the disease and the rural areas account for only a small share in the number of COVID cases reported. But this can be because of low level of testing being done in the rural areas. With relaxation of the lockdown and migrants returning back to their village homes from cities, there can be a reversal of the scenario. The general sentiment in the country is that situation is out of control, health infrastructure is grossly inadequate, testing and treatment is not available to those who 
need it, deaths are mounting, and there is gross medical and humanitarian mismanagement of the crisis by the administration at all levels. There is a sense of impending doom, with a panic filled realization, that in case one develops a serious infection requiring hospital care, there will be none available. Through numerous whatsapp messages and facebook posts, one is inundated with tales of misery and struggles of getting tested and securing a bed and a ventilator in the hospital and how this struggle often ends at crematorium.

News of coronavirus positive cases in India came first from Kerala, a southern state in India, where students from Wuhan in China had returned home in end January and February. Through March, one watched cases rise across country. They were people who had travel histories to various affected countries or who had come in contact with these people. A nationwide Janta (People) Curfew for 14 hours was announced on 22nd March. And on 24th March, a nationwide lockdown of 21 days was announced by Prime Minister Narendra Modi, when India had about 600 confirmed cases of COVID19. The lockdown prohibited all forms of transportation and business activities, allowing only the essential services to remain in operation. Overnight, 1.3. billion people were put under a strict lockdown for which no one had any prior inkling or preparation. It is the world's largest lockdown ever.

I live in Gurugram, a bustling satellite town adjacent to the capital city of Delhi and travel for work everyday to my college in Delhi. Educational institutions had shut a little ahead of the lockdown and many offices too had asked their employees to work from home. So, my family of three was operating from home, at the time when lockdown was announced. As life came to a grinding halt with the announcement of the lockdown, confusion reigned. For all of us, a lockdown was unprecedented. No one I knew, even amongst the older generation (my grandfather, my father, my parents-in-law), had any schema for this word. India has faced many national emergencies in its past, such as: one war with China in 1962 and three wars with Pakistan in 1965, 1971 and 1999, besides the political emergency of 21 months announced by the then Prime Minister Indira Gandhi from 1975 to 1977. The elderly recollected stray incidents of night curfew, rationing of essential groceries etc. during such periods but never such a complete stopping of life. Ofcourse, this also highlights our privileged status in the socio-political hierarchies of India, where people like us have not been affected by the curfews, lockdowns, state surveillance and restrictive life experiences which have been marking the lives of many Indians across the country. All of us were bewildered at the drastic re-orientation in life that this disease brought about, almost overnight.

The initial few days of the Lockdown 1.0 (March 25-April 14) was marked by acute restlessness at being caged inside the house, inspite of having all the amenities required to live comfortably and the opportunity to remain safe from the disease raging outside. One read of people on the streets being stopped, reprimanded and beaten by police for violating the lockdown prohibitions. Gradually, as the lockdown continued, the noises from the streets died down and a pall of silence descended, to be occasionally interrupted by the loud chirpings of different kinds of birds which suddenly appeared from nowhere and the calls of vegetable vendors. As people who could afford to withdraw into their homes began to settle with this new turn in their routines, unsettling and very disturbing visuals of scores of migrant workers thronging bus terminals, railway stations and highways in a desperate bid to leave cities, erupted in front of 
our eyes. The sheer numbers in the media visuals stared at our faces, rendering visible the invisibility of almost 150 million bodies who build and run our cities.

News and social media continued to co-create and transmit the chaos wrecked by the disease pandemic. The xenophobic accusations against Tablighi Jamaat and disinformation about Muslim community, the forceful eviction of doctors and nurses by the landlords, violations of the lockdown regulations, poor plight of Indian farmers and artisans, mounting deaths in the western world which we have always held in awe - all of this have been reaching us through electronic media, which we have come to over rely as a source of connection with the world outside during these times. Through the coronavirus crisis, one has been feeling split between enjoying the pleasures of a simple life and longing to return to one's life before the pandemic, gratitude for the comforts and safety of one's home and guilt over one's privilege, feeling anxious about the well being of oneself and one's near and dear ones and keeping up the faith that there is light at the end of the tunnel. In many ways, digital technology has provided us with a semblance of normalcy and going-on-being in our personal, social and professional lives. Life for people like us has migrated online during this pandemic. Whether it is my son's schooling, my own teaching and evaluation work at college, participating in conferences and webinars, my partner's office work, paying bills, buying the necessities, making donations to the needy, carrying on one's spiritual practice, attending fitness and hobby classes, socializing with friends and family, digital platforms have taken over our lives.

But the future is clearly extremely uncertain for all of us. To compound the pandemic crisis, India has in the past three months faced two cyclones which damaged life and property of people along its eastern and western coastal areas, attack by crop destroying desert locust, several tremors around the capital city igniting fears of a major impending earthquake and border violations by China along the northern borders of India. Against the acute vulnerabilities created by coronovirus disease, these environmental and political threats only serve to exacerbate death like feelings. There is no doubt, that the coronavirus pandemic has taken a vice like grip over our conscious and unconscious minds. Whether we are infected by it or not, we are haunted by its spectre. The most immediate threat is that of life. With unlocking and coronavirus fatigue setting in, people have lowered their guards of social distancing and wearing masks. Thousands of people turned up at Marine Drive, a popular sea-facing promenade in Mumbai, an Indian city with the highest number of COVID19 cases, as soon as the lockdown was lifted. The disease has begun to affect people in our outer social circles, making the fear of illness even more real. And even if one survives, the other threat is to one's livelihood with an already weak economy witnessing a free fall in the wake of the pandemic. The economic impact of the pandemic has also begun to make its presence felt in the close circles of family and friends. A few of them from the media business have been laid off, those in hospitality and travel sector have been handed a pay cut. Small businesses and start ups have suffered losses. Job offer letters to a few students who were hired during the college placement drive have been withdrawn and internship programmes have been cut short.

The social suffering during this pandemic is rampant. But, a crisis like this pandemic should not be wasted. It provides us with opportunities to do a formative assessment of what ails us as a nation and as a global society. It also propels us to rethink our paradigms and social structures. The forthcoming four big and two small stories make 
an attempt to open such a space - for critical investigation and critical imagination - of and for our societies and the discipline of psychology.

\section{\# Story 1: Democracy under Lockdown}

India was the democracy that was never expected to survive. But democracy has persisted here, even in imperfect ways, due to the very idea of India. The idea of India implies chaotic and creaky modes of compromise across identities. The idea of federalism that respects and allows compromise between multiple ethnic and religious identities has prevented the centralization of power in India. The compromises between regional and national identities, across religions and castes, enshrined in federalism are often seen as necessary for the persistence of Indian democracy. This core feature of Indian democracy has suffered many threats in its 73 years of existence by successive governments. In more recent times, the revoking of the constitutional guarantee of special status of Muslim majority territory of Kashmir in August 2019 followed by the promulgation of a citizen registration system (the National Register of Citizens or NRC) and a naturalization process (the Citizen Amendment Bill or CAB) in December 2019 are being perceived by many sections of society as a threat to the federal and secular fabric of the Indian polity.

Close on the heels of such political developments, the pandemic arrived in India in 2020. In the name of a united fight against the pandemic, the National Disaster Management Act was used to impose a nationwide lockdown from March 24, 2020. Yet again, cross party consultation and federal principles were given a short shrift. This is not to argue that the COVID threat should not have invoked a firm policy of physical distancing; the argument is about the fallout. What guarantee do we have that our future democracy will not be governed by this narrative of nationally necessary democratic curtailment? Internet shutdowns, disruptions in mobile services and blackouts are frequently employed tactics by governments to curb dissent. Philosophers like Agamben ${ }^{1}$ have argued that political crises and epidemic crises are alike in that the sovereign powers of the state are extended, and the exception of emergency becomes the norm. Several lockdown measures have been adopted during the pandemic by governments across the globe: ban on the freedom of movement; closure of public spaces such as parks, train stations, airports, museums; shutting down institutions like schools, colleges or universities; prohibition on any gathering - social, cultural or political; and strict observance of social distancing in places where people are permitted to visit. Also, the virus has precipitated an internalisation of deference to governmentality. This is not to say that there is no dissent.

Fear of freedom curtailment has led to civil society protests against the mandatory use of the 'Aarogya Setu App', a digital contact tracing initiative of the Central Government to help stop the spread of COVID19. It is being alleged that in the absence of a legislative guarantee containing a sunset clause, sensitive personal data can be misused for profiling and mass surveillance even after COVID19 outbreak is over. The paranoia around digital surveillance is neither new nor specific to India. India's

\footnotetext{
${ }^{1}$ A. Giorgio (2020, Feb 20) "The Invention of an Epidemic". Quodlibet. Retrieved from https://www. journalpsychoanalysis.eu/coronavirus-and-philosophers/
} 
neighbour, China, is the foremost developer of technologies that facilitate intrusive mass surveillance. There are reports of it using the surveillance technology during the pandemic to penalize people without masks, pinpoint a passenger's location on a flight or train, declare one's identity to take a train or enter a cinema hall, etc. In all likelihood, the status quo has now changed forever - and the improvised solutions of today will inevitably shape the surveillance regimes of tomorrow.

\section{\# Story 2: The 'Measles of Mankind' - Nationalism as a Virus²}

While scholars have more or less univocally rejected nationalism as a viable political program, the return of hardline nationalist regimes suggests that nationalism is not done with us. World over, it is persisting in the current appeal of machismo as political style, the wall-building and xenophobia, the mythology and race theory, the fantastical promises of national restoration. The psychological pull of nationalism has been extensively investigated within social and political psychology. Several psychological motives such as need for self enhancement (Social Identity Theory, Tajfel and Turner 1979), need for belongingness (Optimal Distinctiveness Theory, Brewer 2001), need for meaning to structure choices and reduce uncertainty (Terror Management Theory, Solomon et al. 1991) have been suggested to explain the importance of national identity for people. In the context of the enormous uncertainty created by the pandemic, it is no surprise that people look upto the patronage of nation-states for structure, information and safety. The child-like dependence of people on governments (mai-baap syndrome) provides fertile ground for triggering paternalistic, totalitarian tendencies of nationstate.

The rise of Hindutva nationalism in India must be seen in the context of the evolving political culture internationally and locally. Bhartiya Janta Party - a right wing party has achieved two back to back absolute majority in Indian General Elections of 2014 and 2019 riding on the wave of Hindu Nationalism. India has seen many coalition governments in its 73 years of independent nationhood fought on the basis of agreed upon common programs accommodating diverse political aims and goals. In 2014, the general elections almost had a 'presidential' feel to it, with Narendra Modi as the face of a 'majboot' (strong) rather than 'majboor' (weak and helpless) government which will usher 'Achcche Din' (good times).

Nandy ${ }^{3}$ uses the psychoanalytical lens to unravel the process of harnessing the latent psychological insecurities of the public by the political forces leading to major changes in the political culture of India over the past decades. One such process at work is the conflation of the ideas of nationalism and patriotism amidst Indian public. Patriotism is a sentimental sense of non specific, non ideological territoriality that human beings are naturally endowed with and which they share with mammals and some species of birds and insects (Nandy 1994). It is linked more with a sense of 'home'. Nationalism, on the other hand, is more specific,

\footnotetext{
${ }^{2}$ A quote by Einstein

${ }^{3}$ Ashraf, A. (2019, June 20). One generation will have to bear the cost of what Modi has done: Ashis Nandy analyses the election verdict. The Caravan. Retrieved from https:/caravanmagazine.in/politics/ashis-nandyinterview-2019-election-verdict
} 
ideologically tinged ardent form of 'love of one's own kind' that is essentially ego defensive (in-group favouritism) and includes some degree of fearful dislike or positive hostility to outsiders (out-group denouncement). Nationalism is a compensatory mechanism against sense of being uprooted and loss brought about by forces that underlie creation of nations (for example the partition of India and creation of Pakistan in 1947), urbanization and development. It erases the idea of plurality of ways of life and identities and strengthens the idea of nation-state to which everyone must have a uniform allegiance or loyalty (Nandy 1994). BJP's constant tirade against 'anti-nationals' serves to strengthen the idea of nationalism. The second major development is the rise of cultural nationalism which draws from the support for the idea of a pre-existing Hindu nation. The Hindu majority, in today's times, lack confidence. They feel like a besieged minority and hence cling to the ideologies of Hindutva and Hindu Rashtra for their own survival. The promise of masculinity has long been a draw for Hindu men, especially the youth from the lower socio-economic order, as a means to overcome emasculation, perpetuated upon the myth of loss of power to Muslims, through historical times. These ideologies guard against feelings of vulnerability by means of shared fantasies of past or present grandeur and illusions of belonging to an omnipotent, superior, morally special and historically unique nation. Hindutva ideology sanctions the creation of a masculine state, a state that celebrates valour, aggression and control. Indian middle and elite class want a strong, centralized state that is ready to use coercive measures to drive development, safeguard borders and suppress dissent in times of unrest so visible now. It is within this ideological matrix that Brand Modi is formed which promises to combine strongman politics with liberal economic reforms and steer Brand India into the future.

Populist nationalism is another vicious virus of our times. The next two stories offer more reflections on the intersection amongst caste, class, religious divisions in the nation-state in the pandemic moment.

\section{\# Story 3: Regimes of Despair ${ }^{4}$ - Poverty, Caste and Gender in the Mirror of the Pandemic}

A half naked baby tugs at sheet partially covering its dead mother at the Muzzafarpur Railway Station in Bihar. The woman and her two children had arrived by a Shramik (workers) Special Train on May 25 from Ahmedabad. She collapsed immediately upon reaching the station, possibly due to extreme heat, hunger and dehydration. ${ }^{5}$

Sixteen migrant labourers were crushed to death by a goods train in Maharashtra after they fell asleep on the tracks. The workers were walking towards their home state Madhya Pradesh after they lost their jobs due to the COVID19 lockdown. Most public transportation has already been cancelled due to the lockdown. After walking for about $36 \mathrm{~km}$, these workers started feeling tired and sat on the track for taking some rest.

\footnotetext{
${ }^{4}$ Heading is an abbreviated version of the book title 'Regimes of Despair, Regimes of Narcissism' by Ashis Nandy

5 Tewary, A. (2020, May 27). Migrant workers | Video of baby with dead mother in Bihar railway station goes viral. The Hindu. Retrieved from https://www.thehindu.com/news/national/other-states/migrant-workersvideo-of-baby-with-dead-mother-in-bihar-railway-station-goes-viral/article31685803.ece
} 
They gradually went into deep sleep and an approaching goods train ran over these labourers. ${ }^{6}$

A 14-year-old student, a girl, allegedly committed suicide in Kerala and her parents alleged that she was disturbed as she could not attend online classes since the family did not have either a TV or smartphone. School authorities say the Class 9 student was good in her studies. Her father, a Dalit farm hand, was without work in last three months due to lockdown. ${ }^{7}$

These tragic news reports during COVID 19 pandemic have made us confront the ever-present class, caste, gender based inequalities created by the nation-state. World's biggest lockdown put at peril economy and livelihood of its large population. Consumer durables, automobile, white goods, capital goods, IT, start ups, MSME (Micro, small and medium enterprises) along with the hospitality, travel and tourism sectors are the worst affected. A large number of poor who didn't have the luxury of 'working from home' lost their livelihoods and with that their shelter and food provisions. The slogan 'Stay home, Stay safe' and precautionary measures of washing hands frequently and social distancing mean precious little for the teeming millions who live in crowded quarters or are homeless with little provision of water.

\section{The Migrant Worker: Productive Labour or Diseased Body?}

A prominent emblem of the humanitarian disaster unfolding in India has been millions of migrant workers coming from the central and eastern states to Delhi, Maharashtra, Gujarat to work in construction, small industries and urban informal economy. Most of the migrant workers have a similar story; they were employed in a small unit, which shut down; some got their wages, some were just given enough money to reach home; the contractors and employers asked them to go back to their home, they were not able to pay the rent and buy food without earning. All of a sudden migrant body turned out to be redundant in the city- space. Abandoned by the government, businesses and people they worked for, thousands of such workers began arduous walk of hundreds of kilometers with their families and meager belongings to reach the security and familiarity of their homes in villages and small towns. This is the largest human displacement that the Indian subcontinent has seen since the India-Pakistan Partition in 1947. And the scenes are as tragic.

Along with the physical exertion, these workers had to shield themselves from continuous assault from the police which in many places lathi-charged the marching workers and humiliated them by making them doing sit-ups while holding their ears for violating the lockdown. ${ }^{8}$ In another incident near Bareilly, a group of returnee workers

\footnotetext{
${ }^{6}$ Chaudhary, A. (2020, May 8). Tired migrants sat on tracks for rest, fell asleep. 16 run over by train. Hindustan Times. Retrieved from https://www.hindustantimes.com/india-news/14-migrant-workers-moweddown-by-goods-train-in-maharashtra/story-Z6V8QkOY2CGvdKNHv2uPvI.html

${ }^{7}$ Babu, R. (2020, June 2). Kerala girl allegedly kills self for missing online classes, Rahul Gandhi offers help. Hindustan Times. Retrieved from https:/www.hindustantimes.com/india-news/kerala-girl-allegedly-commitssuicide-for-missing-online-classes-mp-rahul-gandhi-offers-help/story-RbYEOiznZWZPfvELnEkGwI.html

${ }^{8}$ PTI (2020, March 26). Uttar Pradesh cop 'punishes' migrant workers returning home, makes them hop like frogs. The New Indian Express. Retrieved from https://www.newindianexpress.com/nation/2020/mar/26/uttarpradesh-cop-punishes-migrant-workers-returning-home-makes-them-hop-like-frogs-2121946.html
} 
were made to squat and were sprayed with bleach by police in a bid to sanitize them. ${ }^{9}$ The migrants, having no other options, braved their long marches which ultimately resulted in deaths of many due to hunger, dehydration, and exhaustion. Disturbing scenes from Delhi flooded the social media as soon as thousands of workers who were trying to leave for home got stranded in the Delhi-Uttar Pradesh (U.P.) border as all inter-state borders were closed without any measures in place to help the workers. After days of uncertainty, hunger, confusion and hardship, migrants have also been denied entry due to states closing borders or locked up in inhuman conditions in the name of quarantine and sometimes caught in a situation where they have nowhere to go. This is perhaps a classical example to understand the lack of accountability of the state to the migrant workers in the neoliberal regime. State's minimum accountability, lack of social safety net, and hostility to workers solidarity and resistance resulted in migrant worker as 'disposable, individualised, and powerless'. The plight and flight of migrant bodies propelled discourses where the migrant worker was either viewed as the subject of pity and charity, or as the carrier of disease and fear. In both situations, it is indignity thrust on those who utilize their labour to earn and live with dignity. The pernicious situation of the migrant workers caught the attention of United Nations High Commissioner for Human Rights, Michelle Bachelet who, in a statement urged the Indian government to treat the migrants with respect as they are already in a vulnerable position due to their social standing.

The indignity of the returnee workers has engulfed their lives in the villages also. The same remittance-sending migrants, in normal situations, used to get a warm welcome by family and community on their return to villages. Nonetheless, due to the recent pandemic and fear of infection, migrants are not only deserted by the state but also, they don't experience such warmth from family and community. Currently, they are facing stigma in their community that they possibly brought the virus from city. ${ }^{10}$ It shows how the productive body of migrant, which used to provide capital to family and others like a contractor, and employers, is now being treated as the 'body of disease' at the time of health, economic and social crisis. Human body is reduced into mere biological body, bereft of socio- political life, carrier of disease, fit to be disinfected like objects. The plight of the migrant worker is a paradigmatic example of 'naked life' - a concept coined by philosopher Agamben (1998). It is a life where humans are reduced to the upkeep of their basic biological survival rather than humane social survival. It is a life robbed off political status and denuded of any protocol of citizenship. Rather than binding us together, Agamben further muses, the fear of death or losing what is already a naked life "blinds and separates" humans. One may find solace by terming the pandemic as an exceptional situation and the extreme measures as safety measures adopted as an exception. However, this is far from truth. Liberal democracies have been invoking 'the state of exception' ever since. Threat of terrorism has been used post 9/11 to reduce people to 'naked life'. It has become a norm rather than an exception. The social practice of untouchability, to which we turn next, attests

\footnotetext{
${ }^{9}$ Pandey, A. (2020, March 30). Bleach Sprayed On Migrants On Return To UP, Shows Shocking Video. NDTV.com. Retrieved from https:/www.ndtv.com/india-news/coronavirus-india-lockdown-disinfectantsprayed-on-migrants-on-return-to-up- shows-shocking-video-2,202,916

${ }^{10}$ Kumar, C. and Mohanty, D. (2020, May, 11). Migrant workers battle stigma, bias back home. Hindustan Times. Retrieved from https://www.hindustantimes.com/india-news/migrant-workers-battle-stigma-bias-backhome/story-0uuRSEZfoickVOrPU2agGL.html
} 
to how a life with no other value than survival is a social norm. The body, even the shadow, of the untouchable evokes fear, repulsion and an ambivalent fascination. We find a close parallel of this with the black lives in United States.

\section{Torturous Semantics of Tactility: (Un)Touch-Ability during Pandemic}

Will social and physical distancing in a society deeply divided along caste and gender lines accentuate fault lines? Social and physical distancing which today is an important preventive measure for COVID 19, has always been a socially sanctioned practice of collective discrimination against the lower castes, Dalits and tribes in the Indian subcontinent. Since India went into lockdown, 57 families who are part of the Yanadi community and live in Vijaywada, Andhra Pradesh, have been barred from coming out of their village and purchase even essentials like food and medicine. Yanadi community work mainly as waste pickers and drain cleaners and faced segregation even before the pandemic because of their caste. ${ }^{11}$ A pregnant woman of the community complains "We've been locked up here, like prisoners - we live near a milk factory, and there is not a drop of milk for my children to drink. We are called dirty, and they say we spread the disease." Dalits and tribals have been historically forced to take on the jobs related to 'dirt' such as sanitation, waste disposal and manual scavenging. These jobs are considered as essential services during the pandemic but many say that they haven't been given adequate equipment to protect themselves against COVID19. Greater chance of being infected along with the historical burden of social isolation has created ever more difficult circumstances for them. There's little doubt that lower caste Indians are poorer than higher castes. Poverty makes lower castes more vulnerable during emergencies. "India has 600,000 villages and almost in every village a small pocket on the outskirts is meant for Dalits," said Paul Divakar, a Dalit activist from the National Campaign on Dalit Human Rights. "This settlement is far from health care centers, banks, schools and other essential services. During times like COVID19, the aid may not even reach this small pocket."

A study conducted on 215 quarantined rural migrants in Bihar and U.P., including Dalits, OBC (Other Backward Caste) and upper castes, revealed that untouchability and vertical distance got diluted for them during these times. ${ }^{12}$ It reported that their experience was largely around saving their lives - 'jaan bachawe aur ghar pahuchne ki chinta ke samne aur kuchh nahi sujhat rahe' [Apart from worrying about our lives and reaching home, we could envisage nothing else]. Secondly, the memory of suffering played an important role in reshaping the meaning of their identity. An experience narrated by an $\mathrm{OBC}$ youth is that in those difficult times we all became one caste, 'dukhiyaron ka caste' [the caste of miserables]. While the experience of withstanding the misery together may have created a temporary sense of fraternity in this sample of workers, the truth is that caste system is a system that denies a possibility

\footnotetext{
${ }^{11}$ Sur, P. (2020, April, 16). Under India's caste system, Dalits are considered untouchable. The coronavirus is intensifying that slur. CNN. Retrieved from https:/edition.cnn.com/2020/04/15/asia/india-coronavirus-lowercastes-hnk-intl/index.html

${ }^{12}$ Ghosh, A. (2020, June 3). Caste is deeply ingrained in our social system ... but an emergency like a pandemic gives jolts and shocks to it. The Times of India blogs. Retrieved from

https://timesofindia.indiatimes.com/blogs/Addictions/caste-is-deeply-ingrained-in-our-social-system-but-anemergency-like-a-pandemic-gives-jolts-and-shocks-to-it/
} 
of fraternal existence. It is one of the most inert structures of Indian social system. The question that faces social scientists is - Why so?

As a reply to this, B.R. Ambedkar, the architect of Indian Constitution and a staunch champion of Dalit rights said that Hindus cannot destroy the caste system without destroying their religion because Hinduism rests on the foundations of inequality. Ambedkar pointed out that both men and god have connived in the practice of untouchability:

The Hindu social order is based on the doctrine that men are created from different parts of the divinity.....The Brahmin is no brother to the Kshatriya because the former is born from the mouth of the dignity while the latter is from the arms. The Kshatritya is no brother to the Vaishya because the former is born from the arms and the latter from his thighs. As no one is brother to the other, no one is keeper of the other.

The doctrine that the different classes were created from the different parts of the Divine body has generated the belief that must be divine will that they should remain separate and distinct (1967; p.100).

The Hindu instinct to create separations in social life is not merely sustained by belief or by rules of work. There is a bigger evil at play, especially in the context of untouchability: the dark narcissism of the higher castes and the cruel, cold pain it demands and relishes (Geetha 2011). The caste imagination that persists even in modern sectors of life needs the untouchable, his continuous humiliation being the condition of our social order. In the context of pandemic, one witnesses it by hailing the sanitation and waste disposal workers as essential service providers without providing them with adequate safety gear or dignity of labour.

Indian developmental democracy fidgets with the question "Who is to be included?" But Ambedkar marks the "What?" In the context of the opportunity structure of jobs, education and political power in secular-modern India, the real task is to include not the Dalit worker, Dalit student and Dalit political candidate but the 'Dalit' of these persons, i.e. histories of humiliation and hurt and longing for dignity and self-respect amongst Dalit life forms? (Dhar 2015) The public discourse of Indian nation state is dominated by a pet language triad: democracy, development and secularism. But liberty is now too often seen as operating on the logic of exclusion, in which the excluded categories, like the anti-nationals (usually the Communists and Ambedkarites) are denied civil liberties in the name of national security. Inclusion is on the terms of erasure of difference.

\section{Engendering Coronavirus Pandemic}

It is highly likely that newer forms of purity and pollution and notions around untouchability will see a sharp increase along with gendered violence. Due to fear in returning to cities immediately, there will be greater pressure on land and agricultural activities. One expects the return of some kind of patron-client relation, subtle practices of bondage and new forms of money lending coming back in village society. Dominant castes in the villages have a high chance of deploying fear and anxiety associated with COVID19 to put the low caste labour migrants in a complicated situation. What price would womenfolk pay when their husbands, unable to return shark loans coax them to 
face debtors, hoping to get some respite from repayment? And what would happen to children, especially girls, when their education comes to a halt for months on end? We know that early or child marriage becomes the norm in uncertain times, as does trafficking of women and children. The unfortunate incident of the poor Dalit girl in Kerala who committed suicide due to inability to take online classes highlights the intersectionality of caste, poverty and gender disadvantages which precludes one from benefits of education and other modes of social advancement, not just during pandemic but also otherwise. Will decreased production and distribution of condoms, oral pills and emergency contraception pills, and reduced access to abortion (both surgical and medical) force women to go through unwanted pregnancies or resort to unsafe methods to terminate pregnancy? Loss of wages, jobs, boredom, withdrawal from alcohol and other drugs have far-reaching consequences for men as well as for the women in the household. Increased domestic violence due to forced proximity has increased worldwide; worse still, women are now cloistered within the four walls with their batterers. In response to the alarming incidence of gender-based violence during the pandemic, the UN chief has exhorted governments to treat legal, medical and related responses to domestic violence as emergency services. In heterosexual relationships, women are more likely to be the lower earners, meaning their jobs are considered a lower priority when disruptions come along. And this particular disruption could last months, rather than weeks. Some women's lifetime earnings will never recover. With the schools closed, many fathers will undoubtedly step up, but that won't be universal, and unpaid care burden will fall in the lot of women.

\section{\# Story 4: Fear of Virus, Phobia of Islam}

......no group has played a greater role in spreading the deadly coronavirus far and wide than the Tablighi Jamaat ('Proselytising Society'), a transnational missionary movement of the Deobandi branch of Sunni Islam. ${ }^{13}$

Notices were put up in some localities dominated by the majority community barring entry of Muslim vendors. One of the notices at Krishnanagara in Thokkottu near Mangaluru, read, "In the interest of public, muslim vendors are banned from entry until coronavirus is completely contained. ${ }^{14}$

Over the past few months of pandemic, it is difficult to say what is spreading faster in India- Coronavirus or Islamphobia? Pandemics are known to heighten fear and suspicion which may be wholly unrelated to the reality of virus. Paradoxically, it is not the virus which is literally seen as the object of fear - it is "other people", all seen as potential carrier of illness and death. We learn through social experience that 'foreigner', the 'poor', the 'religious other' are few such targets to be treated as 'dangerous' and blamed, shamed and stigmatized (Volkan 1988). The urge to protect, distance, disinfect, hide oneself from them is paramount. Othering leads to avoidance, segregation, abuse and end in pogroms. The pandemic illustrated yet again, how fascist forces of the

\footnotetext{
${ }^{13}$ Chellaney, B. (2020, 20 April). The Threat from Tablighi Jamaat. Open the Magazine

${ }^{14}$ Mohammad, A. (2020, April 8). Muslim vendors barred after social media misinformation. Deccan Herald. Retrieved from https:/www.deccanherald.com/state/top-karnataka-stories/muslim-vendors-barred-aftersocial-media-misinformation-823066.html
} 
world engage in the politics of enmity by deciding unilaterally who will be the political enemy (China and Muslims, as most popular choices). Schmitt (2007) writes, "The political enemy need not be morally evil or aesthetically ugly; he need not appear as an economic competitor, and it may even be advantageous to engage with him in business transactions. But he is, nevertheless, the other, the stranger; and it is sufficient for his nature that he is, in a specially intense way, existentially something different and alien, so that in the extreme case conflicts with him are possible" (p.27).

A big Islamic congregation held in mid March by the Tablighi Jamaat in Delhi, became a trigger to further fan the politics of hate against Muslims during the pandemic. For the three day congregation held before India had declared COVID19 as a health emergency, many attendees had flown in from countries with active COVID19 cases. Many of them were infected by the virus and led to the spike in cases in India. Soon, the terms 'Tablighi' and 'Jamaati' were added to the slur 'Paki' and 'Mullah' constituting the Indian vocabulary of communal hate. While the organization's leadership acted irresponsibly, government action was also lax. Why did Delhi Government not stop a gathering like this inspite of Centre's advice to states to avoid or postpone mass gatherings till the pandemic was contained? Large sections of Indian media's reporting of the event has lacked nuance, denouncing the Jamaat as terrorists and their irresponsible act as motivated monstrous act of 'Corona Jihaad'. Explicit hate mongering was witnessed on news channels, whatsapp and social media. To manufacture and weaponize this narrative, media has eliminated mention of similar gatherings by Hindus, Sikhs and other. Fake stories of Muslim patients flashing nurses and demanding biryani in quarantine centers grabbed the front page headlines and occupied centre stage in raucous television news shows. Social boycott was compounded by economic boycott fostered with fake whatsapp videos of Muslim vendors smearing vegetables and fruits with their saliva. In a related development, Delhi Police is being accused of witch hunting the organizers of anti CAA protests in the wake of lockdown. Police arrested these Muslim women under various charges for being a part of the protest led by them in Jamia University and Shaheen Bagh, Delhi against the controversial Citizenship Amendment Act (CAA), the proposed National Register of Citizens (NRC) and the National Population Act (NPA) during January and February, 2020.

Constitutionally, India is a secular country with a majority of Hindus, which constitute $80 \%$ of the population, with Muslims being $14.23 \%$, Christians $2.30 \%$, Sikhs $1.72 \%$, Buddhists $0.70 \%$ and Jains $0.32 \%$. Muslims constitute the largest and what Gayer and Jaffrelot (2012) call, "precarious" minority owing to a complex history of conflict, which has continued from as early as AD 1026; from the invasions of the Indian subcontinent by Muslim rulers from Central Asia, to the formation of the Mughal empire lasting two centuries and finally the Partition of India in 1947. The conflict between the two communities is manifested in demolition of mosques (Babri Masjid Demolition, 1992), communal violence (Godhra, 2002), allegations of 'love jihad' and more recently in lynching in the name of cow vigilantism. How does one reconcile the secular foundations of Indian nation state with rise in Hindutva ideology since the 1990s and the corresponding increase in Islamophobia?

In a scathing critique of secularism, Nandy (1997) said that communalism and secularism are not sworn enemies but are 'disowned doubles of each other'. Said (1978) writes, "[It] is not to say that the old religious patterns of human history and destiny and 'the existential paradigms' were simply removed" (p. 121) from the secular 
state; rather they were "reconstituted, redeployed, redistributed in the secular frameworks" (pg.121). Infact what the Hindu right is doing in contemporary Indian politics is that it is mobilizing the "will of a modernizing interventionist state in order to erase the presence of the religious or ethnic particularisms from the domains of law or public life, and to supply, in the name of 'national culture', a homogenized content to the notion of citizenship" (Chatterjee 1994, p.176). In conflating Hindutva with national, it identifies religions other than itself, i.e., the religions of minorities, as problematic and promotes fear, violence and intolerance against minorities. In the large group Hindu psyche, due to psycho-political reasons, the Muslim becomes the near exact equivalent of Jews. From the destruction of Somnath temple, to the Mughal rule to the partition of India everything has been rendered as "chosen traumas" by the Hindutva rhetoric. In making the Muslim responsible for the chosen trauma, he is made the enemy and Muslims, a hated, persecuted and feared minority. Muslim is, thereby, created as a religious category, which is, in turn, incompatible with being an Indian, thus 'anti-national'.

Taken together, these four stories emerging from the Indian context co-create a solid critique of populist and sectarian nationalism pervasive worldwide. The pandemonious times have once again spotlighted the totalitarian tendencies of nation-states, their politics of enmity and the trumping of mere biological survival over moral, social relations by making exceptional situations the norm. Through the stories above, one can diagnose violent and unjust intergroup relations based on caste, class, race, religion, gender, nationality perpetuated by liberal democracies as key locus of human problems. Are there any solutions? Is an alternative world possible? Can psychology aid us in this enterprise? We will address these questions after the next two stories of cultural psychological resourcefulness of the Indian ethos.

\section{\# Story 5: Hindu Epics, Ayurveda and Yoga - Local Solutions for Global Problems}

During the lockdown, India's national broadcaster Prasar Bharati began to re-telecast on Doordarshan channels its old television shows of 1980s and early 1990s, when satellite television had not made its entry in India. The ones that enjoyed the highest popularity on their re-runs were the Hindu epic dramas Ramayana and Mahabharata. During one of his interactions with people of his constituency in the course of the lockdown, Prime Minister invoked the epic Mahabharat and said, "Mahabharata war was won in 18 days, but the battle which the entire country is fighting against coronavirus will take 21 days. Our aim is to win this war in 21 days." He further added, "While the Mahabharata war was won under the guidance of lord Krishna, 1.3 billion citizens of India will help the nation fight against COVID19."15 He also alluded to Ramayana and asks the citizens to remain within the 'Lakshmana Rekha', a cultural metaphor to denote the ethical limits of any action, traversing which leads to drastic consequences. In the context of the pandemic, it was intended to be an exhortation to abide by the lockdown otherwise, the demonic virus will attack like Ravana, a demon

\footnotetext{
${ }^{15}$ Pandey, N. (2020, March 25). Mahabharata war won in 18 days, but fight against coronavirus will take 21 days, says Modi. The Print. Retrieved from https://theprint.in/india/mahabharata-war-won-in-18-days-butfight-against-coronavirus-will-take-21-days-says-modi/388267/
} 
king, did to Sita, the Queen, in Ramayana. Echoing the present government's Hindutva ideology, the Brazilian Prime Minister wrote to the Indian Prime Minister, comparing India's efforts to contain the pandemic to Hanuman's efforts to bring Sanjeevani Booti to cure Lord Rama's brother Lakshmana in the epic Ramayana.

The decision of the government to re-telecast two significant Hindu epic dramas at prime time alongwith Shri Krishna, Vishnu Purana and Upanishad Ganga, which are also based on sacred Hindu texts, is being touted as a strategy to encash the lockdown to push its revivalist, saffron politics further. In November 2019, the Supreme Court verdict paved the way for the building of Ram Temple at a site in Ayodhya, city of Lord Ram's Birth, where supporters of Hindu right groups demolished a sixteenth century mosque in 1992, bringing relief to a longstanding narcissistic wound of the mass Hindu collective. The TV show, Ramayana which ran from 1987 to 88 is widely believed to have played a big role in fueling the demand for building the temple in place of mosque in Ayodhya. Professor of Media Studies at the New York University, Rajagopala (2001) writes, "The Ramayana serial overlapped with the most crucial phase of the Janmabhoomi movement, when it changed from an ominous but still relatively obscure campaign into the dominant issue before the country... With such publicity given to its pre-eminent symbol, the god-king Ram, the Hindu nationalist BJP was emboldened to declare, by the middle of 1989, that the Ayodhya movement had 'reached a state and status in Indian public life when it was no more possible to ignore its effect in politics"'(p.90). The show reified a standard story of Ram, sidelining the countless renderings of Ram Katha across India and South East Asia, in the minds of people. By putting him on a pedestal and making him an epitome of virtue, the show amplified his appeal even among those Hindus who may not have been Ramworshippers.

Notwithstanding the politics, it cannot be denied that these television shows have tremendous psychological appeal to provide to the audience during coronavirus crisis a devotional experience and a feeling of hope that all wars end with the destruction of evil and triumph of good. Culturally speaking, both the texts highlight a central motif of Hindu life - Dharma. Profound moral lessons on life and death are found in our everyday cultural and communicative routines. Dharma is variously translated as law, moral duty, right action, conformity with the truth of things. Ram in Valmiki Ramayana was the embodiment of Dharma and Krishna in Vyasa's Mahabharata enabled Arjuna to resolve the moral dilemma i.e. 'Dharma Sankat' in the war against his kith and kin for the throne. Shweder et al. (1990) note that in the duty based moral codes 'It is the performance of duty, not the defense of liberty or personal conscience, that stimulates feelings of righteousness' (pp. 147-148). At a time when individuals, corporates and governments deal with difficult choices between rights or duty, personal profit or public welfare, life or livelihood, these epics provide necessary education in ethical sensibility. In the duty based religious traditions, rights are inseparable from duties and responsibilities. Aziz (1999) stated that "Gandhi, opined, about the Universal Declaration of Human Rights, that rights arose from duties well done. Even the right to live, he argued, came from doing the duty of world citizenship, although this was not in the legal/constitutionalist sense of the term (p.45).

Also, the theme of 'exile' looms quite significantly in these texts. The god-King Rama was exiled for 14 years and was sent to forests. Pandavas in Mahabharata too spent 13 years in exile. Exile represents the unfamiliar, the wilderness and the unknown. If one thinks deeply, there is a lesson for life during pandemic crisis here. Life 
in lockdown is like a life in 'exile'. The flow of normal life has been disrupted lending an aura of 'strangeness' to going ons during lockdown. Much like the encounter with demons during exile, we are encountering the dreaded virus. During the exile, the characters in the epic move out of their normative world, travel, encounter the unknown and the unfamiliar and through such confrontational experiences acquire the wisdom to rule in a more Dharmic way. Can we, as a nation, too make use of this extraordinary experience to reflect on our life, polity and its structure, rethink the 'normal' and renew our commitment to act as per what is right and true? What is being depicted in these texts is the striving to lead a Dharmic life from which the humanity, at large, has been deflected. Can our 'new normal' be structured around the duty based moral code of 'Dharma'?

\section{Striking a Death Blow: Coronavirus in the Throes of Traditional Practices of Health}

During this health emergency, cultural ideas about health and well being are being extensively discussed in personal conversations amongst people. Given the lack of fool proof treatment in western medicine, i.e. pharmacological drug and vaccination, much attention is being paid to strengthening the immunity of body to prevent and fight against the viral infection. Ayurveda, a traditional Indian system of medicine, usually dubbed in the west as an alternative system of medicine, is receiving a lot of attention worldwide. The Rasayana therapy of Ayurveda is a dedicated stream of medication for immune promotion, antidegenerative and rejuvenating health care. Several medicinal plants used in Rasayana have attracted the attention of the scientists worldwide. Plants and herbs like Tulsi, Ginger, Turmeric, Amla, Garlic, Clove etc. are widely used in Indian cooking and are known to have many immunity boosting effects. The reference to Sanjeevani booti by Brazilian Prime Minister is also drawn from Ayurveda. Indians are known to be very concerned with food - not only its preparation but also the effects it has on the body and mind. Diet and its waste products, like feces and urine, are closely monitored because a person is literally what he eats. Diet is viewed as the mainstay of physical and mental health as also the cause of disease.

In 2014, a new ministry was formed in the Indian Central Government called the Ministry of AYUSH (Ayurveda, Yoga \& Naturopathy, Unani, Siddha and Homoeopathy) with the explicit aim of developing education, research and propagation of indigenous alternative medicine systems in India. The website of the ministry hosts resources that provide recommended measures for self care to boost immunity during the COVID19 crisis. A few of these measures include, drinking warm water through the day, drinking golden milk (turmeric mixed in milk), taking kadha (decoction) of Tulsi (basil) Dalchini (cinnamom), Kalimirch (black pepper), Shunthi (dry ginger) and Munakka (raisin), applying coconut oil in the nostrils and eating Chyawanprasha (an ayurvedic jam consisting of various herbs). Whatsapp messages and videos are attesting to the benefits of these ayurvedic measures during this health pandemic. There has been a record spike in the sales of Chyawanprasha since the start of the COVID19 crisis in India. $^{16}$

\footnotetext{
${ }^{16}$ Singh, N. (2020, April 11). Chyawanprash sees boost in demand. Economic Times. Retrieved from https:// economictimes.indiatimes.com/industry/cons-products/food/chyawanprash-sees-boost-in-demand/ articleshow/75091605.cms?utm_source=contentofinterest\&utm_medium=text\&utm_campaign=cppst
} 
Besides Ayurveda, Yoga is also an Indian export to the world which is gaining recognition in the domain of health and well being. Yoga, an ancient philosophy, is more than just a set of physical exercises (asanas). It is a philosophy and practice of coming together, 'union' (the literal meaning of yog), of the individual consciousness with the universal consciousness. It is a method of inquiry in the nature of mind, which emphasizes practice and direct experience. Asanas (postures), meditation, pranayam (breathing exercises) and chanting are the four practices of Yoga. There are four main paths of yoga that lead to the ultimate goal of union with universal consciousness Raja Yoga (The path of Self Discipline), Bhakti Yoga (The path of Self-Surrender), Jnana Yoga (The path of Self Awareness) and Karma Yoga (The path of Selfless Action). The Ministry of AYUSH launched a campaign called 'Yoga at Home, Yoga with Family' for the International Yoga Day celebrated on June 21st, to encourage the practice of Yoga to counter the effects of the viral infection as well as to stay healthy overall.

The question of local paradigms of medicine are crucial in regard to the pandemic. Richards (2016) has shown how local knowledge and a "people's science" helped end the EBOLA epidemic in Sierra Leone. India is witnessing one of the lowest mortality rate of COVID19. This raises issues about the generalizability of understandings of how bodies may react to medicine; whether curative regimes can be universalized; and finally, about taking seriously local paradigms of knowledge about the body and its location within community. ${ }^{17}$

What is particularly interesting about Indian mindset is how faith in indigenous systems of Ayurveda and Yoga is maintained alongside the faith in western medication system. The pharmaceutical industry in India is a flourishing one and Indians throng to doctors and hospitals for their medical needs. India is also a popular destination for medical tourism in the world. But Indians tend to view health and disease in a more complex way than westerners. A disease can be understood due to a chemical imbalance or a viral/bacterial infection leading to allopathic cure. Alongside, it can also be conceptualized, as per Ayurveda, due to disequilibrium of the five elements (panch bhuta) that build all manifest life - earth, water, fire, air, space, which can be set right by diet, herbal concoctions and external applications. This disequilibrium may be compounded by problems related to personal lifestyle such as lack of routine and exercise rectified by yogic discipline and asanas. In case of stubborn persistence of disease, fault may be found in maleficent plenatary positions, as suggested by astrology which can be rectified by 'graha puja' (prayer offered to planets). This can be further traced to bad karma of the previous birth, for which the meditation, chanting and karmic correction as suggested by Yoga can be followed as remedies. Prime Minister Modi's exhortation to light lamps, clang plates, ring bells during the early part of Indian Lockdown has been linked to a form of belief system prevalent in India in which Coronavirus can be overcome by energies released by celestial bodies and objects. Yagnas and Pooja (worship rituals) are also believed to dispel crisis.

The cognitive dissonance theory will fail to understand that "tradition and technology sleep in the same bed in India" (Varma 2004, p. 142). Inconsistent and contradictory beliefs, values, norms and practices are held not only by different sets

\footnotetext{
${ }^{17}$ Menon, D. (2020, Aug 7). Viral histories: Will Covid-19 help us generate new thinking? Scroll.in. Retrieved from https://scroll.in/article/969649/viral-histories-will-covid-19-help-us-generate-new-thinking
} 
of Indians, but the same Indians own them without any discomfort or dissonance. Roland (1988) found that "There is much more of an ability [of Indians] to live with inconsistency and dissonance than tends to be characteristics of most Westerners" (pp. 4-5). Carl Jung quipped that Indians "do not mind seemingly intolerable contradictions". Comfort with paradoxes and contradictions cannot be reduced to hypocrisy or duplicity. It is a unique psychological tendency which allows a person to combine incongruent elements in creative ways to make the best of a situation. From an indigenous psychology perspective, Indians' tolerance for diverse and discrepant ideas is a creative and adaptive behaviour which enables them to embrace the pluralistic worldviews available to them due to their unique historical-cultural lineage.

\section{\# Story 6: We, the People of India - Role of Indian Civil Society in the Pandemic}

India has witnessed success stories worthy of international recognition. One of these is the containment of COVID19 in Asia's largest slum, Dharavi, in Mumbai. A heavily densely populated area, it quickly became a COVID hotspot. But aggressive testing and tracing initiative by the state government prevented the disease from breeding uncontrollably. Kerala, the first Indian state to register the COVID19 case, has also been able to keep the number of cases down through quick and effective action. A laudable feature of Kerala's fight against coronavirus has been community engagement. ${ }^{18}$ Kudumbashree, an empowered women's network in Kerala, formed close to 1.9 lakh WhatsApp groups with 22 lakh neighbourhood groups (NHGs) to educate on key safety measures as advocated by the government during lockdown. Community Kitchen initiative through the Local Self Government Department (LSGD) with the support of Kudumbasree has provided more than 8,651,627 free meals to the labourers, those who are in quarantine, isolation, destitute and other needy persons. Distribution of millions of cooked meals and provision of free ration under the Public Distribution Scheme to those in need is reflective of a well-thought and a caring response and relief strategy.

India has also witnessed a prompt and energetic response by the private sector, high net individuals, philanthropic foundations and programs, development sector and private individuals in complementing and enabling government efforts to address some critical immediate needs as well as contributing towards longer term recovery efforts and future preparedness related to the pandemic. The Indian private sector is seen collaborating in efforts to provide PPE kits to the front line health and sanitation workers, build isolation and hospital facilities, source ventilators, give financial assistance to poor and needy. ${ }^{19}$ People from the film industry and cricket - the two obsessions of the Indians - have extended a helping hand in making donations to national funds, offering their offices as quarantine facilities, funding NGOs providing basic necessities and food to the migrant workers. The grassroot and community based

\footnotetext{
${ }^{18}$ WHO (2020, 2 July). Responding to COVID19. Learnings from Kerala. Retrieved from https://www.who. int/india/news/feature-stories/detail/responding-to-covid-19\%2D\%2D-learnings-from-kerala

${ }^{19}$ Barman, A. and Guha, R. (2020, April 8). India Inc's battle groups against Covid-19 get going. Economic Times. Retrieved from https:/economictimes.indiatimes.com/news/company/corporate-trends/india-incsbattle-groups-against-covid-19-get-going/articleshow/75036251.cms?from=mdr
} 
organizations have been supplementing government's efforts to disseminate accurate information about the disease and piloting isolation facilities in rural India. The Sikh Community, a religious minority community of India, has done commendable work of supplying meals to the healthcare workers, migrant workers, homeless, those in isolation and quarantine facilities all over the world. ${ }^{20}$ It is an extension of their religious philanthropic practice of 'langar' which refers to treating everyone in need of food, irrespective of their class, caste, gender, race, as Guru's (Preacher's) guest and providing them with food in a spirit of equality, love and kindness. Many Tablighi Jamaat volunteers who have recovered from coronavirus are now queuing up in hospitals in different parts of India to donate plasma for critical patients undergoing treatment. ${ }^{21}$ There have been many shining examples of help and cooperation extended by private individuals, young and old, during this pandemic.

Given the Indian spirit of entrepreneurship, India has seen a quick response by its domestic manufacturers to produce testing kits, ventilators and treatment drugs needed to deal with the pandemic. India's reliance on imports for testing kits and ventilators is steadily declining because of the efforts of domestic manufacturers in filling in the gap in the supply chain. Another silver lining to the cloud is that Glenmark, India based Pharmaceutical company, has recently launched a new antiviral drug as treatment for mild to moderate symptoms of the coronavirus disease.

World over, we are witnessing the rise of people power. Monbiot ${ }^{22}$ writes, "Power has migrated not just from private money to the state, but from both market and state to another place altogether: the commons. All over the world, communities have mobilised where governments have failed." Bollier and Helfrich (2019) define the commons as "a social form that enables people to enjoy freedom without repressing others, enact fairness without bureaucratic control ... and assert sovereignty without nationalism." The commons are neither capitalist nor communist, market nor state. They are an insurgency of social power, in which we come together as equals to confront our shared predicaments. There is a sense of 'We are all in this together', experiencing the same fear and trembling.

These six big and small stories of Indian response to the COVID19 pandemic shows how narratives of crisis are simultaneously global and local, disparate and conflictual. On one hand are the dystopian narratives of authoritarian regime strengthening and social cohesion being undermined. On the other hand is the more optimistic narrative of expanding social empathy, everyday heroes, and widening social solidarity.

\footnotetext{
${ }^{20}$ Singh, B. (2020, June 10). Sikhs Are Risking Their Safety To Help People Across The World, During The COVID-19 Pandemic. Indiatimes. Retrieved from https://www.indiatimes.com/trending/social-relevance/ sikhs-are-real-heroes-whore-risking-their-lives-to-help-people-across-the-world-during-covid-19-510135.html ${ }^{21}$ Krishnan, M. (2020, 29 April). Cured Muslims in India donate blood plasma to critical COVID19 patients. $R f i$. Retrieved from https://www.rfi.fr/en/international/20200429-cured-muslims-in-india-donate-bloodplasma-to-critical-covid-19-patients

${ }^{22}$ Monbiot, G. (2020, March 31). The horror films got it wrong. This virus has turned us into caring neighbours. The Guardian. Retrieved from https://www.theguardian.com/commentisfree/2020/mar/31/virusneighbours-covid-19
} 


\section{'Post Coronial' Psychology of and for a 'Post-Coronial' World}

The pandemic has opened out a pandora box of debates. Was the COVID19 pandemic, a Force Majeure event, an unforeseen event beyond the control of anyone and whose consequences cannot be avoided or mitigated? Or was it a disaster waiting to happen and be repeated? Is it a transitory state of exception requiring extreme measures or is it steadily transforming the way humans perceive and regulate themselves and others? Is it going to change the world for the better or the worse?

Extreme crisis cannot be captured by ordinary language. Severe personality disorganization such as Schizophrenia is marked by language disturbances such as word salad and neologisms. The pandemic moment too has witnessed the coining of many new words, neologisms, to capture the transformations taking place at the personal and collective levels. We need conceptual tools and methodologies to make sense of the 'new normal' that is taking shape in front of us beyond our control. We also need them to imagine 'new normal' that is possible and that we shape with more ethical sensibilities, an anti-thesis of the world as we know it. Everyone is asking - What will the new normal look like? - as hopes, fears and futures unfold against the specter of coronavirus pandemic. Can Psychology aid us in this enterprise? Post Coronial world needs a Post Coronial Psychology. In this section, I shall sketch broad challenges and implications facing the 'Post-Coronial' Psychology.

Let us first examine what are the new socio-political realities unveiling before us and psychology's role in making sense of it. As mentioned in Story\#1, governments world over are tightening the surveillance regimes in the name of contact tracing and control of the virus. Though, not a new phenomena, it is definitely being normalized and legitimized for the times to come in the guise of the pandemic. A neologism, Coronopticon ${ }^{23}$ (a play of words combining Foucault's Panopticon and Coronavirus) has been coined to refer to the surveillance regimes brought in focus during the COVID19. Psychology needs to rise to the challenge of providing answers to what it is like to be living in 'coronopticon' - heavily surveilled environments during the coronavirus pandemic? Psychology is making some inroads in researching on people's knowledge and experience of technological surveillance but it needs to, in the words of social psychologists Haslam and Reicher (2002), "devote far more effort to developing a science of surveillance" (p.13). Several questions beg answers here - What kinds of affects and thoughts emerge as a consequence of surveillance? How knowledge of surveillance leads to self regulation by ordinary people? Is surveillance inherently repressive? How do we understand participatory surveillance (Albrechtslund 2008) and 'bottom-up' surveillance, which Mathiesen (1997) terms 'synopticism'? Are there social norms around when surveillance is acceptable and when it is not; when it evokes feelings of safety and when breach of privacy? Will the legitimized use of face masks as a fallout of pandemic become a form of resistance to the visual modes of surveillance?

\footnotetext{
23 (2020, Mar 26) Creating the Coronopticon. Economist. Retrieved from https:/www.economist.com/ briefing/2020/03/26/countries-are-using-apps-and-data-networks-to-keep-tabs-on-the-pandemic
} 
Pandemocracy ${ }^{24}$ is another neologism that has been coined to reflect the biopolitics of liberal democracies during the pandemic which has created the split between 'making live' and 'letting die'. The lesser worthy - the poor, the untouchables, the blacks, the religious others, the old and infirm, the girl child, the political dissenter have always been the pick for the latter option. Pandemocracy has sharpened and legitimized the split by aggravating the fear of death. Psychology can help in developing an understanding of how relational proximity is undermined to follow the new rule of social distancing? How is disease and distance desouling us? What are the deleterious effects on family and community life as the sick are abandoned by the healthy and dead by the living? How to understand the lived experience of those from whom selfsacrificial care and services is extracted by the state by hailing them as corona-warriors? With touch becoming the new villain, will more categories of people be added to the list of 'untouchables'? With masks becoming the social norm, will more sections of society be pushed behind the veil of invisibility?

\section{A Re-turn to Indigenous Wisdom for the Future of Post-Coronial Psychology}

While these may appear to be a grim diagnosis of what the 'new normal' looks like, let us not forget that crisis like pandemics are social laboratories which reveal consequences of past (in)actions and opens out possibilities of re-envisioning a just, equitable future. COVID19 is leaving no stone unturned to highlight to the entire humanity the disastrous consequences of intentional or willful not-knowing of the obvious emergencies confronting us due to lack of interest or denying/concealing the situation as it conflicted with other self-serving interests. It is also pushing us to engage with alternative futures in an ever more urgent way. But as we engage with them, we are either led back into the realm of 'non knowing' and the various forms it manifests in such as doubt, probability, uncertainty, ambiguity, non-linearity and complexity or we get caught up in frenzy of the depressive status-quo which closes off the 'future'. So, what do we do? How do we use this historical moment to open out the realm of 'thinkable futures', since the present is a travesty? Here, the clinical and mental health traditions in Psychology come to our aid. They alert us that 'capacity to think' is not a given, especially so in a crisis situation, which creates trauma, fragmentation, impasse and stagnation. We can transform our relationship with not-knowing by becoming tolerant of ambiguity, complexity and interdependencies and making it a resource rather than a liability for decision making. The acceptance of ambiguities and interdependence is a fact of life in the Indian way of life. Much can be learnt about the concern highlighted by the pandemic to transform self-other relations in the direction of justice and care for the global society as well as for the natural environment if we break the fetters of intellectual colonization and soar in the indigenous space of insight and wisdom. Voices to decolonize psychological knowledge and indigenize modern psychology to make it more relevant to their local and cultural practices have been insistent and loud for over half a century now. We are at a juncture in the discipline where 'there can be no psychology without culture'. To paraphrase Dhar and Siddiqui (2013),

\footnotetext{
24 (2020, Apr 23). Would be autocrats are using COVID19 as excuse to grab more power? Economist. Retrieved from https://www.economist.com/international/2020/04/23/would-be-autocrats-are-using-covid-19as-an-excuse-to-grab-more-power
} 
indigenous psychologies have the twin aims of offering - the 'indigenous' logic of psyche as well as the logic of 'indigenous' psyche. Seen this way, culturally infused forms of psychology would contribute theoretically and methodologically both to global psychological concerns and local subjectivities.

The endeavour in the following discussion is to dwell in the indigenous intellectual traditions of India and recover theoretical ideas to reformulate the exploitative and unjust relationships that characterize human society and polity as well as ecological degradation. The discussion will draw upon the Indian way of understanding emotional intelligence as well as the concepts of dharma and cosmic collectivism that offer possibilities of reorientation of social and psychological life in times to come.

\section{Emotional Intelligence and Indian Psychology}

A neologism that originated in India provides an apt starting point for us. The neologism is - 'Karunavirus' - a substitution of word 'Karuna' for Corona. The pleas in Indian media and society to feel or rather be infected with 'Karuna' (the mood of pathos) in times of Corona is more than just a clever play of words. It is the need of the hour. It is an emotionally intelligent response to the human condition of suffering evoking the dharma (social duty) of offering care to those who need it. Karuna is one of the eight rasas listed by Sage Bharata in his Natya Shastra, composed approximately in 3 century A.D. The Indian text deals with poetic, dramaturgical, and aesthetic experiences and details how music, dance, theatrical performances can induce rasa in the spectator. Rasa is a refined mental state to which the dancer/poet and spectator get transported to. It is a meta-emotion - a sui generic form of consciousness. The individual (jiva) is thought of as an experiencer (bhokta), whose positive as well as negative affect (bhoga) is taken as a whole - a universe in itself (bhava-visva). Unlike the Western view of emotions which sees it as an aspect of self, "rasa theory is embedded in a holistic view of human condition in which emotional experience is viewed in relation to the human condition, and coping with its problem" (Paranjpe 2009, p.5).

The Western models of Emotional Intelligence (EI) (Goleman 1995; Mayer and Salovey 1997; Bar-On 2000) conceptualize it as trait or ability located within the individual. However, in the Indian context, culture-specific ways of behaving such as respecting elders, concern for others, and fulfilling one's duties are basic to the notion of EI (Sibia et al. 2004). Sibia et al. (2004) identified the following aspects of emotionally intelligent functioning in the Indian context: pro-social values ("respecting elders," "being affectionate"), social sensitivity ("concern for others," "empathizing with others", "control of negative emotions"), action tendencies ("being helpful", "disciplined") and affective states ("happy disposition", "optimism"). This indigenous framework places emotions at the very heart of issues of self (aatman-brahman) and morality (dharma). Since the Indian view of self emphasizes connectedness with animate, inanimate and divine realms as the fundamental reality (cosmic collectivism), the notion of emotional intelligence reflects concerns, expressions and behaviors that are intertwined with the person's relationships with others, rather than focusing solely on the self. The Indian notion of emotional intelligence also refers to the capacity to carry on one's dharma (responsibilities and duties towards self and others) as is reflected in the pro-social values and social sensitivity domains highlighted by Sibia 
et al. (2004). It is this spiritual realization of the connectedness of human beings and not voluntary relations between autonomous individuals (which is the dominant understanding in the Western Psychology) as the fundamental truth of life which needs to be respected and acted upon as it holds the promise of making future human relations harmonious.

\section{Cosmic Collectivism: An Indigenous Reformulation of Self-Other Relationships}

The indigenous concept of 'Cosmic collectivism' also offers possibilities to develop fresh theoretical thinking around large groups' functioning and their intergroup dynamics, the need of which has been affirmed by Stories \#2,3 and 4. The thing is amply clear that we cannot do away with group life as group identification is a central human need. Thus, any new imagination of politics and sociality must respect such needs for group belongingness. The western ideal of autonomous individualism vilifies human longings for intimacy and group membership and thus condemns human beings to a life of isolation and alienation. Pandemic has borne the testimony of how due to social/ physical distancing, mental health problems increased manifold. Seen from the perspective of an agentic, autonomous selfhood, collectivism appears to be an unsatisfactory solution as group is perceived as demanding allegiance, conformity and subordination of personal goals to group goals. In short, a sense of belongingness is at the cost of erasure of individuality. This tension between individualism and collectivism is a unique feature of cultural psychology of Euro-Americans because of its assumption of the dichotomy between individual and social. In contrast, Cosmic collectivism reflects a worldview that the universe consists of diverse forms of animate and inanimate elements that are compatible as well as conflicting. But they all are interconnected and held together by an underlying sense of unity derived from being parts of the ultimate Reality, the Brahman. Brahman is a universal spirit and individual souls/selves are the aatman. The latter emerges from the former temporarily and merges with it ultimately: "living beings as individualized centres of awareness that are like distinct waves of the endless expanse of an oceanic single principle fundamentally characterized by consciousness" (Sankaracharya cited by Paranjpe 2010, p. 24). It means that every aatman is essentially the Brahman - the cosmos is a collective. One of the mantras of the Shankhayana Aranyaka extolled, "I am Brahman" This understanding is essential to the existential reality of life. Plants and animals, rocks and sand particle, water and fire - all are derived from the ultimate reality - Brahman and share the cosmic consciousness. This unity is the core of the cosmic collectivism. It is because of their shared entity, that Gods and Goddesses in India appear in human, animal and plant form. Animals, plants and stones are worshipped. It was in this frame of the united universe that, according to the Taittiriya Upanishad, the human being was conceptualized as having five layers, like concentric sheaths of onion, from outer physical to the innermost (pure, conscious) self. They are (a) the body (annamaya) created by food, embedding the person into the physical environment; (b) vital breath (praanamaya), or bodily functions; (c) sensory functions (manomaya) such as attending, perceiving, feeling, etc.; (d) cognitive sheath (vijnaanamaya) consisting of ideas and concepts that help one understand the world; and (e) joyous core (aanandamaya), that is aatman, the true self (Paranjpe 1998, p. 163).

Even while being enmeshed into the collectives of inanimate, animate and divine, human beings suffer from a sense of separation from Brahman, and strive to get union 
with Him - moksha (salvation), which is the terminal goal of life. This journey for the union is essentially individualistic in nature. The journey starts with what the human beings are and heads towards what they should become; that is, from biological being to the spiritual one. The chitta, the dispositional mind, is at the core of biological being. It consists of impulses and desires and is unstable, restless and turbulent. However, the chitta is also inherently oriented to attain moksha (salvation) by passing through a number of major milestones. The milestones are marked as the life goals of artha (earning money and acquiring material things), dharma (discharging personal duties and obligations according to the age, gender and caste-based roles) and kaama (seeking sensuous including sexual pleasure). The spiritual transformation of the aatman entails transcendence of the narrowness of individual self and expansion to include not only the near and dear ones in the family, but also the larger collectives and in fact for the whole universe. The whole universe becomes the family (Vasudhaiva kutumbakam):

One begins with concern for oneself and gradually expands one's ego to encompass one's community and ultimately the entire world. Similarly in one of the verses of the Mahabharata it is stated that for the sake of the clan one gives up the individual (person), for the sake of the village one gives up the clans, for the sake of the country (janapada) one gives up the village, and for the highest good one gives up the earth. Concern for others has been given the highest place and the target is the larger group (Sinha 1988, p. 20).

In this indigenous wisdom, we find solutions to the individual-social dichotomy and antagonism and to ingroup bias and outgroup hostility. Cosmic collectivism can serve as an antidote against the biggest virus of today's times - Pseudospeciation. Erik Erikson (1985), a psychoanalyst, proposed the term "pseudospeciation" to describe the tendency of human beings - as a species - to differentiate themselves from other members of their species. This idea is, perhaps, best presented in Erikson's (1962) description of the human need "to feel that they are of some special kind (tribe or nation, class or caste, family, occupation, or type), whose insignia they will wear with vanity and conviction, and defend (along with the economic claims they have staked out for their kind) against the foreign, the inimical, the not-so-human kinds" (p. 2).

To conclude, the pandemic has revealed the 'common fate' of humankind and simultaneously, paradoxically, sharpened the divisions amongst human beings. For 'Post-Coronial' psychology, it has set the challenge of developing culturally informed global and local frameworks to re-envision harmonious self-other relationships and critiquing such traditions and conventions that perpetuate intergroup inequalities and violence. A critical-cultural approach is the future of Post-Coronial Psychology.

Data Availability NA

\section{Compliance with Ethical Standards}

\section{Conflict of Interest NA}

Code Availability NA 


\section{References}

Agamben, G. (1998). Homo Sacer: Sovereign power and bare life. Stanford: Stanford University Press.

Albrechtslund, A. (2008). Online social networking as participatory surveillance. First Monday, 13(3).

Aziz, N. (1999). The human rights debate in an era of globalization: Hegemony of discourses. In V. N. Peter (Ed.), Debating human rights (pp. 31-55). New York: Routledge.

Bar-On, R. (2000). Emotional and social intelligence: Insight from the emotional quotient inventory. In R. Bar-On \& D. A. Parker (Eds.), The handbook of emotional intelligence (pp. 363-388). San Francisco: Jossey-Bass.

Bollier, D., \& Helfrich, S. (2019). Free, fair, and alive: The insurgent power of the commons. New Society Publishers.

Brewer, M. B. (2001). Ingroup identification and intergroup conflict: When does ingroup love become outgroup hate? In R. D. Ashmore \& L. Jussim (Eds.), Social identity, intergroup conflict, and conflict reduction. Rutgers series on self and social identity, vol 3 (pp. 17-41). London: Oxford University Press.

Chatterjee, P. (1994). Secularism and toleration. Economic and Political Weekly, 29, 1768-1777.

Dhar, A. (2015). What if, one is always already included? in Seminar (674), October 2015.

Dhar, A., \& Siddiqui, S. (2013). At the edge of (critical) psychology. Annual Review of Critical Psychology, $10,506-548$.

Erikson, E. H. (1962). Reality and actuality. Journal of the American Psychoanalytic Association, 10(3), 451474.

Erikson, E. (1985). Pseudospeciation in the nuclear age. Political Psychology, 6, 213-217.

Gayer, L. and Jafferlot, C. (2012). Muslims of the Indian City: from centrality to marginality. In L. Gayer, \& C. Jafferlot (Eds.), Muslims of the Indian City: Trajectories of Marginalization (pp. 1-24). India: Harper Collins.

Geetha, V. (2011). Bereft of being: The humiliation of Untouchability. In G. Guru (Ed.), Humiliation: Claims and context. New Delhi/New York: Oxford University Press.

Goleman, D. (1995). Emotional intelligence. New York: Bantam Books.

Haslam, S. A., \& Reicher, S. (2002). A user's guide to the experiment-Exploring the psychology of groups and power: Manual to accompany the BBC video. London: $\mathrm{BBC}$ Worldwide.

Mathiesen, T. (1997). The viewer society: Michel Foucault's 'Panopticon' revisited. Theoretical Criminology, $1(2), 215-233$.

Mayer, J. D., \& Salovey, P. (1997). What is emotional intelligence? In P. Salovey \& D. Sluyter (Eds.), Emotional development and emotional intelligence: Implications for educators (pp. 3-31). New York: Basic Books.

Nandy, A. (1994). The illegitimacy of nationalism. New Delhi: Oxford University Press.

Nandy, A. (1997). The twilight of certitudes: Secularism, Hindu Nationalism, and other Masks of Deculturation. Alternatives: Global, local, political Vol. 22, No. 2, pp. 157-176, Sage Publications.

Paranjpe, A. C. (1998). Self and identity in modern psychology and Indian thought. New York: Plenum.

Paranjpe, A. C. (2009). In Defence of an Indian approach to the psychology of emotion. Psychological Studies, 54(1), 1-22.

Paranjpe, A. C. (2010). Theories of self and cognition: Indian psychological perspectives. Psychology and Developing Societies, 22(1), 5-48.

Rajagopala, A. (2001). Politics after television: Hindu nationalism and the reshaping of the public in India. Cambridge University Press.

Richards, P. (2016). Ebola: How a people's science helped end an epidemic. London: Zed books.

Roland, A. (1988). In search of self in India and Japan: Towards a cross-cultural psychology. Princeton: Princeton University Press.

Said, E. (1978). Orientalism. London, UK: Penguin.

Schmitt, C. (2007). The Concept of the Political. (George D. Schwab, trans.) Chicago: University of Chicago Press.

Shweder, R. A., Mahapatra, M., \& Miller, J. G. (1990). Cultural and moral development. In J. W. Stigler, R. A. Shweder, \& G. Herdt (Eds.), Cultural psychology: Essays on comparative human development (pp. 130-204). Cambridge: Cambridge University Press.

Sibia, A., Misra, G., \& Srivasatava, A. K. (2004). Towards understanding emotional intelligence in the Indian context-perspectives of parents, teachers and children. Psychological Studies, 49, 114-123.

Sinha, D. (1988). Basic values and behavioural dispositions in the context of national development. In U. Kim, H. C. Triandis, C. Kagitcibasi, S. C. Choi, \& G. Yoon (Eds.), Individualism and collectivism: Theory, method, and application (pp. 31-55). Thousand Oaks: Sage. 
Solomon, S., Greenberg, J., \& Pyszczynski, T. (1991). A terror management theory of social behavior: The psychological functions of self-esteem and cultural worldviews. In M. E. P. Zanna (Ed.), Advances in experimental social psychology, vol 24 (pp. 93-159). San Diego: Academic.

Tajfel, H., \& Turner, J. C. (1979). An integrative theory of intergroup conflict. In W. G. Austin \& S. Worchel (Eds.), The social psychology of intergroup relations (pp. 33-47). Monterey: Brooks/Cole.

Varma, P. (2004). Being Indian: The truth about why the 21st century will be Indians. New Delhi: Viking, Penguin.

Volkan, V. D. (1988). The need to have enemies and allies. From clinical practice to international relationships. Northvale, NJ: Jason Aronson.

Publisher's Note Springer Nature remains neutral with regard to jurisdictional claims in published maps and institutional affiliations.

Dr Parul Bansal is an Assistant Professor of Psychology at Lady Shri Ram College for Women, University of Delhi, India. Her doctoral work was a psychoanalytically informed qualitative research exploring individuation and ideological formation amongst Indian youth. Her areas of academic interests are: Critical Psychology, Cultural Psychology, Psychoanalysis and Qualitative Research. She has two books to her credit: Bansal, P. (2013). Youth in contemporary India: Images of identity and social change. Springer (ISBN: 978-81-3220714-6) and Bansal, P. (2019). Psychology: Debates and Controversies. New Delhi: Sage (ISBN: 978-93-5328083-3).

Besides, she has also written several book chapters, presented academic papers and published in journals. 